\title{
PERENCANAAN PEMBELAJARAN DI LEMBAGA SEKOLAH
}

\author{
Sugiyarti \\ Nim. 836366609 \\ Email: sugiyarti341@gmail.com
}

Perencanaan dalam definisi dan teori penelitian para ahli yang dipelopori oleh seorang yang bernama Hidson menyatakan bahwa teori perencanaan tersebut mencakup : sinoptik, inkremental, transaktif, advokasi, dan radial. Selanjutnya di kembangkan oleh tanner (1981) dengan nama teori SITAR sebagai penggabungan dari taksonomi Hudson. Pembahasan yang diuraikan tentang teori perencanaan secara umum, namun itu juga berlaku secara spesifik untuk perencanaan pendidikan.

Perencanaan dalam definisi dan teori penelitian para ahli yang dipelopori oleh seorang yang bernama Hidson menyatakan bahwa teori perencanaan tersebut mencakup : sinoptik, inkremental, transaktif, advokasi, dan radial. Selanjutnya di kembangkan oleh tanner (1981) dengan nama teori SITAR sebagai penggabungan dari taksonomi Hudson. Pembahasan yang diuraikan tentang teori perencanaan secara umum, namun itu juga berlaku secara spesifik untuk perencanaan pendidikan.

Cakupan tentang teori perencaan tersebut dibahas secara ringkas pada makalah berikut ini :

\section{Teori Sinoptik}

Teori ini terkadang disebut dengan bahasa lain ; system planning, rational system approach, rasional comprehensive planning. Menggunakan model berfikir system dalam perencanaan, sehingga objek perencanaan dipandang sebagai suatu kesatuan yang bulat, dengan satu tujuan yang disbebut visi. Langkah-langkah dalam perencanaan ini meliputi ; pengenalan masalah,

1. mengestimasi ruang lingkup problem

2. mengklasifikasi kemungkinan penyelesaian,

3. menginvestigasi problem,

4. memprediksi alternative,

5. mengevaluasi kemajuan atas penyelesaian spesifik.

\section{Teori Incemental}


Didasarkan pada kemampuan institusi dan kinerja personalnya. Bersifat desentralisasi dan tidak cocok untuk jangka panjang. Jadi perencanaan ini menekankan perencanaan dalam jangka pendek saja. Yang dimaksud dengan desentralisasi pada teori ini adalah si perencana dalam merencanakan objek tertentu dalam lembaga pendidikan, selalu mempertimbangkan faktor-faktor lingkungan.

\section{Teori Transactive}

Menekankan pada harkat individu yang menjunjung tinggi kepentingan pribadi dan bersifat desentralisasi, suatu desentralisasi yang transactive yaitu berkembang dari individu ke individu secara keseluruhan. Ini berarti penganutnya juga menekankan pengembangan individu dalam kemampuan mengadakan perencanaan.

\section{Teori Advocacy}

Menekankan hal-hal yang bersifat umum, perbedaan individu dan daerah diabaikan. Dasar perencanaan tidak bertitik tolak dari pengamatan secara empiris, tetapi atas dasar argumentasi yang rasional, logis dan bernilai (advocacy= mempertahankan dengan argumentasi).

Kebaikan teori ini adalah untuk kepentingan umum secara nasional. Karena ia meningkatkan kerja sama secara nasional, toleransi, kemanusiaan, perlindungan terhadap minoritas, menekankan hak sama, dan meningkatkan kesejahteraan umum. Perencanaan yang memakai teori ini tepat dilaksanakan oleh pemerintah/ atau badan pusat.

\section{Teori Radikal}

Teori ini menekankan pentingnya kebebasan lembaga atau organisasi lokal untuk melakukan perencanaan sendiri, dengan maksud agar dapat dengan cepat mengubah keadaan lembaga supaya tepat dengan kebutuhan.

Perencanaan ini bersifat desentralisasi dengan partisipasi maksimum dari individu dan minimum dari pemerintah pusat / manajer tertinggilah yang dapat dipandang perencanaan yang benar. Partisipasi disini juga mengacu kepada pentingnya kerja sama antar personalia. Dengan kata lain teori radikal menginginkan agar lembaga pendidikan dapat mandiri menangani lembaganya. Begitu pula pendidikan daerah dapat mandiri menangani pendidikannya.

\section{Teori SITAR}

Merupakan gabungan kelima teori diatas sehingga disebut juga complementary planning process. Teori ini menggabungkan kelebihan dari teori diatas sehingga lebih lengkap. Karena teori ini memperhatikan situasi dan kondisi masyarakat atau lembaga 
tempat perencanaan itu akan diaplikasikan, maka teori ini menjadi SITARS yaitu S terakhir adalah menunjuk huruf awal dari teori situational. Berarti teori baru ini di samping mengombinasikan teori-teori yang sudah ada penggabungan itu sendiri ada dasarnya ialah menyesuaikan dengan situasi dan kondisi lembaga pendidikan dan masyarakat. Jadi dapat kita simpulkan bahwa teori-teori diatas mempunyai persamaan dan pebedaannya. persamaannya:

1. Mempunyai tujuan yang sama yaitu pemecahan masalah

2. Mempunyai obyek perencanaan yang sama yaitu manusia dan lingkungan sekitarnya.

3. Mempunyai beberapa persyaratan data, keahlian, metode, dan mempunyai konsistensi internal walaupun dalam penggunaannya terdapat perbedaan penitikberatan.

4. Mempertimbangkan dan menggunakan sumberdaya yang ada dalam pencapaian tujuan Sedangkan Perbedaannya adalah :

1. Perencanaan sinoptik lebih mempunyai pendekatan komprehensif dalam pemecahan masalah dibandingkan perencanaan yang lain, dengan lebih mengedepankan aspekaspek metodologi, data dan sangat memuja angka atau dapat dikatakan komprehensif rasional. Hal ini yang sangat minim digunakan dalam 4 pendekatan perencanaan yang lain.

2. Perencanaan incremental lebih mempertimbangkan peran lembaga pemerintah dan sangat bertentangan dengan perencanaan advokasi yang cenderung anti kemapanan dan perencanaan radikal yang juga cenderung revolusioner.

3. Perencanaan transactive mengedepankan faktor - faktor perseorangan / individu melalui proses tatap muka dalam salah satu metode yang digunakan, perencanaan ini kurang komprehensif dan sangat parsial dan kurang sejalan dengan perencanaan Sinoptik dan Incremental yang lebih komprehensif.

4. Perencanaan advocacy cenderung menggunakan pendekatan hukum dan obyek yang mereka ambil dalam perencanaan adalah golongan yang lemah. Perencanaan ini bersifat sosialis dengan lebih mengedepankan konsep kesamaan dan hal keadilan social

5. Perencanaan Radikal seakan - akan tanpa metode dalam memecahkan masalah dan muncul dengan tiba-tiba (spontan) dan hal ini sangat kontradiktif dengan pendekatan incremental dan sinoptik yang memepertimbangkan aturan - aturan yang ada baik akademis/metodologis dan lembaga pemerintahan yang ada.

Secara konsepsional, bahwa perencanaan pendidikan itu sangat ditentukan oleh cara, sifat, dan proses pengambilan keputusan, sehingga nampaknya dalam hal ini terdapat 
banyak komponen yang ikut memproses di dalamnya. Adapun komponen-komponen yang ikut serta dalam proses ini adalah :

1. Tujuan pembangunan nasional bangsa yang akan mengambil keputusan dalam rangka kebijaksanaan nasional dalam bidang pendidikan.

2. Masalah strategi adalah termasuk penanganan kebijakan (policy) secara operasional yang akan mewarnai proses pelaksanaan dari perencanaan pendidikan.

Ada beberapa prinsip dalam perencanaan pendidikan, yaitu:

1. Perencanaan itu interdisiplinair, karena pendidikan itu sendiri sesungguhnya interdisiplinair terutama dalam kaitannya dengan pembangunan manusia.

2. Perencanaan itu fleksibel dalam arti tidak kaku tetapi dinamis serta responsif terhadap tuntunan masyarakat terhadap pendidikan.

3. Perencanaan itu objektif rasional dalam arti untuk kepentingan umum bukan untuk kepentingan subjektif sekelompok masyarakat saja.

4. Perencanaan itu tidak mulai dari nol tetapi dari apa yang dimiliki, ini berarti segala potensi yang tersedia merupakan aset yang perlu digunakan secara optimal.

5. Perencanaan itu wahana untuk menghimpun kekuatan secara terkoordinir untuk digunakan secermat mungkin untuk kepentingan pembangunan pendidikan.

6. Perencanaan itu disusun dengan data, perencanaan tanpa data tidak memiliki kekuatan yang dapat diandalkan.

7. Perencanaan itu mengendalikan kekuatan sendiri, tidak bersandarkan pada kekuatan orang lain.

8. Perencanaan itu komprehensif dan ilmiah dalam arti mencakup keseluruhan aspek pendidikan dan disusun secara sistematis.

\section{B. Teknik-Teknik Perencanaan Pendidikan}

Dalam pembuatan perencanaan diawali dengan teknik perencanaan. Teknik perencanaan dapat berjalan dengan baik apabila unsur-unsur pendukung terbentuknya dapat berjalan dengan lancar. Unsur-unsur tersebut antara lain:

1. Sebelum melakukan suatu perencanaan harus mengetahui keadaan sekarang dan apa yang ingin direncanakan.

2. Merencanakan sesuatu dengan target agar tujuan tercapai atau adanya perubahan.

Teknik-teknik dalam perencanaan pendidikan bertujuan membantu perencanaan dalam mengambil keputusan. Teknik yang dipilih dalam uraian ini adalah teknik yang dapat 
digunakan oleh para perencana pada semua tingkat perencanaan. Teknik-teknik tersebut antara lain yaitu:

\section{Diagram Balok (Bar Chart)}

Diagram Balok bisa disebut juga Diagram Gannt. Diagram Balok memberikan gambaran tentang kegiatan terperinci dari suatu proyek, waktu memulai sikap kegiatan, dan lamanya kegiatan tersebut. Dalam suatu proyek biasanya kita menjumpai beberapa kegiatan yang harus dilakukan secara berurutan, yang berarti suatu kegiatan tidak dapat dilakukan sebelum kegiatan lain diselesaikan. Itulah sebabnya Diagram Gannt, garis mengenai jadwal kegiatan diletakkan secara tumpang tindih.

Kelemahan dari Diagram Balok adalah:

A. Hubungan antara satu kegiatan dengan kegiatan lainnya tidak tergambarkan atau hubungan kebergantungan tidak ditunjukkan.

B. Tidak bisa diidentifikasi kegiatan mana yang merupakan kegiatan kritis. Kegiatan kritis adalah kegiatan yang tidak dapat ditunda, apabila tertunda mengakibatkan gangguan terhadap penyelesaian keseluruhan proyek.

Menurut Timan dalam Damayati (2013) beberapa hal yang dipandang sebagai kelemahan dari diagram ini antara lain:

A. Hubungan antara satu aktivitas dengan aktivitas lain tidak ditunjukkan.

B. Kegiatan kritis (kegiatan yang sedemikian pentingnya sehingga penundaan kegiatan tersebut akan mengganggu atau menunda keseluruhan proyek) tidak dapat diidentifikasikan).

C. Penyempurnaan (updating) informasi karena adanya perubahan waktu mulai atau waktu penyelesainnya suatu kegiatan menyebabkan diagram ini harus diganti seluruhnya.

Meskipun demikian sampai saat ini Diagram Balok masih banyak digunakan terutama untuk kegiatan-kegiatan yang tidak kompleks.

\section{Diagram Milstone}

Diagram Milstone disebut juga diagram struktur perincian kerja yang menggambarkan unsur fungsional suatu proyek dengan keterkaitannya secara fungsional. Struktur ini dibuat berdasarkan proyek yang disusun secara hierarkis. Apabila proyek secara keseluruhan dianggap sebagai sistem, maka proyek itu dipecah menjadi bagian-bagian sistem (subsistem).

\section{Rencana Operasi}


Menurut Buku IIB Materi Dasar Pendidikan Program Akta Mengajar V(1983/1984: 28) dalam merencanakan proyek, harus menjawab dan menganalisa pertanyaan "Apakah yang harus dilakukan?"; kemudian "Bagaimana hal itu akan dilakukan?" Lalu dua pertanyaan tersebut diperluas, misalnya seperti berikut:

a. Oleh siapakah kegiatan itu dilaksanakan?

b. Sumber apakah (man, money, material) yang diperlukan?

c. Kapan dan dalam waktu mana kegiatan itu dilakukan?

d. Di mana akan dilakukan?

Tiap pertanyaan di atas bisa diuraikan lebih lanjut secara detail. Pertanyaanpertanyaan memerlukan jawaban yang kemudian dinyatakan dalam bentuk keputusankeputusan. Hasil akhir dari keputusan tersebut adalah suatu rencana kerja yang sering disebut dengan Rencana Operasi atau RENOP.

\section{PERT dan CPM (Network Planning)}

\section{PERT(Program Evaluation and Review Technique)}

Menurut Richard dalam Fattah (2013: 63) PERT diartikan sebagai "teknik manajemen dalam merencanakan dan mengendalikan proyek-proyek yang bersifat nonrepetitive atau tak berulang." Sedangkan menurut Buku IIB Materi Dasar Pendidikan Program Akta Mengajar V (1983/1984: 31) "PERT merupakan representasi diagramatik yang juga berguna dalam merencanakan kegiatan sekaligus alat manjemen yang efektif'. Kegunaan PERT ini terletak pada tingkat ketelitian analisis dari suatu kegiatan, urutan, serta hubungan logisnya. PERT dapat digunakan hampir dalam segala hal kegiatan, mulai dari memformulasikan rencana sampai kepada evaluasi dari implementasi suatu rencana.

\section{Model Perencanaan Pendidikan}

Menurut Kamus Besar Bahasa Indonesia, kata model diartikan sebagai contoh, pola acuan ragam, macam, atau barang tiruan yang kecil dan tepat seperti yang ditiru. Jadi model perencanaan pendidikan dapat diartikan sebagai contoh atau acuan yang digunakan dalam penyusunan sebuah perencanaan, lebih umum membahas rencana dan kebijakan tertinggi dalam instansi pendidikan. Menurut Suprayogi (2014) model dan metode perencanaan pendidikan tentunya berbeda dengan model dan metode perencanaan pengajaran, perencanaan pendidikan cakupannya lebih luas dan lebih umum menyangkut rencana dan kebijakan yang dikeluarkan oleh pengambil kebijakan tertinggi dalam instansi pendidikan. 
Sedangkan model perencanaan pengajaran memuat komponen sistem pembelajaran dan unsur kegiatan yang dilakukan, baik oleh guru maupun siswa dalam proses pembelajaran. Ada beberapa macam-macam model perencanaan dalam pendidikan yaitu seperti berikut:

\section{Model Perencanaan Komprehensif}

Model ini digunakan untuk menganalisis perubahan-perubahan dalam sistem pendidikan secara keseluruhan. Selain itu berfungsi sebagai suatu patokan dalam menjabarkan rencana-rencana yang lebih spesifik ke arah tujuan-tujuan yang lebih luas.

Model ini berfungsi sebagai patokan dalam menjabarkan rencana-rencana yang lebih spesifik atau khusus ke arah tujuan yang lebih global dan luas. Metode ini juga dapat digunakan untuk menganalisis perubahan secara luas dalam suatu sistem pendidikan secara menyeluruh.

\section{Model Target Setting}

Model ini diperlukan dalam upaya melaksanakan proyeksi atau memperkirakan tingkat perkembangan dalam kurun waktu tertentu. Dalam persiapannya dikenal model untuk analisis demografis dan proyeksi penduduk, model untuk memproyeksikan jumlah siswa yang terdaftar dalam sekolah, dan model untuk memproyeksikan kebutuhan tenaga kerja.

\section{Model Pembiayaan dan Efektivitas Biaya}

Model ini digunakan untuk menganalisis proyek-proyek dalam kriteria efisien dan efektivitas ekonomis. Dengan model ini dapat diketahui proyek yang paling fisibel dan memberikan suatu perbandingan yang paling baik di antara proyek-proyek yang menjadi alternatif penanggulangan masalah yang dihadapi. Penggunaan model ini dalam pendidikan didasarkan pada pertimbangan bahwa pendidikan itu tidak terlepas dari masalah pembiayaan. Dan dengan sejumlah biaya yang dikeluarkan selama proses pendidikan diharapkan dapat memberikan keuntungan tertentu.

Penggunaan model ini dalam pendidikan didasarkan bahwa pendidikan tidak terlepas dari biaya yang diharapkan membawa keuntungan atau benefit. Dapat dikatakan model ini sama dengan model untung rugi.

\section{Model PPBS}

PPBS (Planning, Programming, Budgetting System), dalam bahasa Indonesia adalah sistem perencanaan, penyusunan program, dan penganggaran (SP4). Menurut Fattah (2013: 51) model ini bermakna bahwa perencanaan, penyusunan program, dan penganggaran 
dipandang sebagai suatu sistem yang komprehensif untuk pengambilan keputusan yang efektif.

Untuk memahami PPBS secara baik, maka perlu kita perhatikan sifat-sifat esensial dari sistem ini. Esensi dari PPBS adalah sebagai berikut:

1. Memerinci secara cermat dan menganalisis secara sistematik terhadap tujuan yang hendak dicapai.

2. Mencari alternatif-alternatif yang relevan, cara yang berbeda-beda untuk mencapai tujuan.

3. Menggambarkan biaya total dari setiap alternatif, baik biaya langsung ataupun tidak langsung, biaya yang telah lewat ataupun yang akan datang, baik biaya yang berupa uang ataupun biaya yang tidak berupa uang.

4. Memberikan gambaran tentang efektifitas setiap alternatif dan bagaimana alternatif itu mencapai tujuan.

5. Membandingkan dan menganalisis alternatif tersebut, yaitu mencari kombinasi yang memberikan efektifitas yang paling besar dari sumber yang ada dalam pencapain tujuan (Jujun S., 1980).

Model ini bermakna bahwa perencanaan, penyusunan program, dan penganggaran dipandang sebagai suatu sistem yang tak terpisahkan satu sama lainnya. PPBS merupakan suatu proses yang komprehensif untuk pengambilan keputusan yang lebih efektif. Menurut Kast dan Rosenwzweig (1979) PPBS merupakan suatu pendekatan yang sistematik yang berusaha untuk menetapkan tujuan, mengembangkan program-program untuk dicapai, menemukan besarnya biaya dan alternatif, dan menggunakan proses penganggaran yang merefleksikan kegiatan program jangka panjang.

Harry J. Hartley (1968) mengemukakan bahwa PPBS merupakan proses perencanaan yang komprehensif yang meliputi program budget sebagai komponen utamanya.

Ciri-ciri SP4 (sistem perencaan penyusunan program dan penganggaran) menurut Timan (2004) adalah sebagai berikut:

1. SP4 dimulai dari penetapan tujuan nasional. Jadi perencanaan dengan SP4 bersifat dari atas ke bawah (top down).

2. Menghubungkan tujuan umum dengan program yang bersifat khusus.

3. Menghubungkan program dengan sumber-sumber yang diperlukan.

4. Menghubungkan masukan instrumental dengan uang yang diperlukan. 
Tujuan penggunaan SP4 (sistem perencaan penyusunan program dan penganggaran) menurut Timan (2004) adalah sebagai berikut:

1. Membuat agar perencanaan jangka panjang merupakan kegiatan rutin.

2. Memungkinkan rencana dan program dapat ditinjau kembali setiap saat untuk dapat diadakan revisi.

3. Mengadakan klasifikasi kegiatan organisasi dalam bentuk program dan hasil yang diharapkan dan bukan lagi berdasarkan jumlah jabatan atau yang hal-hal lain.

4. Meningkatkan koordinasi antar berbagai program yang dirancang untuk mencapai tujuan.

5. Mendorong perencanaan terpadu antar Departemen/ bagian.

6. Memungkinkan pengukuran kemajuan suatu program sesuai dengan pertahapannya.

\section{PENUTUP}

\section{A. KESIMPULAN}

Perencanaan pendidikan adalah suatu proses menetapkan keputusan yang berkaitan dengan tujuan yang akan dicapai, sumber sumber yang akan diberdayakan, dan teknik atau metode akan dipilih secara tepat untuk melaksanakan tindakan selama kurun waktu tertentu agar penyelenggaraan pendidikan dapat dilaksanakan secara efektif, efisien dan bermutu. Depdikbud (1982), mengemukakan langkah-langkah yang ditempuh dalam proses penyususnan perencanaan pendidikan yaitu: (a) pengumpulan dan pengolahan data, (b) diagnosis, (c) perumusan kebijakan, (d) perkiraan kebutuhan masa depan, (e) perhtungan biaya, (f) penetapan sasaran, (g) perumsan rencana, (h) perincian rencana, (i) implementasi rencana, $(\mathrm{j})$ evaluasi rencana, dan $(\mathrm{k})$ revisi rencana. Dengan adanya langkah-langkah perencanaan pendidikan tersebut diharapkan pendidikan di Indonesia akan semakin maju. Masalah pendidikan di Indonesia seakan menjadi masalah pula untuk pemerintah dalam merencanakan Sistem Pendidikan Nasional. Sistem Pendidikan Nasional selama ini seakan belum meng-cover tujuan pendidikan nasional. Tujuan pendidikan nasional begitu mulia, tetapi implementasinya tidak sanggup mewujudkannya. Perencanaan sistem pendidikan ini akan sesuai dengan tujuan pendidikan nasional, apabila masalah dalam pendidikan yang telah dibahas dapat teratasi.

\section{B. SARAN}

Permasalahan pendidikan yang terjadi di Indonesia mengakibatkan rendahnya kualitas pendidikan di Indonesia. Rendahnya kulitas pendidikan di Indonesia menyebabkan keterbelakangan Sumber Daya Manusia Indonesia yang pada akhirnya 
berdampak pada keterlambatan pembangunan di Indonesia. Hal ini tentu tidak di inginkan, oleh karena itu marilah kita bersama-sama mengatasi berbagai permasalahan yang terjadi. Dengan meningkatkan kualitas pendidikan berarti sumber daya manusia yang terlahirakan semakin baik mutunya dan akan membawa bangsa ini bersaing secara sehat dalam segala bidang di dunia internasional.

Daftar Pustaka

Departemen Pendidikan dan Kebudayaan. 1983/1984. Perencanaan Pendididkan Buku IIB Materi Dasar Pendidikan Program Akta Mengajar V. Jakarta: Ditjen Pendidikan Tinggi.

Matin. 2013. Dasar-dasar Perencanaan Pendidikan. Jakarta: Rajawali Pres.

Prihantoro, R. 2010. Arti Perencanaan Menurut Para Ahli, (Online) (https://h0404055.wordpress.com/2010/04/02/arti-perencanaan-menurut para-ahli/), diakse 14 Januari 2015.

Sulfemi, Wahyu Bagja. (2015). Kemampuan Pedagogik Guru. Prosiding Seminar Nasional. STKIP Muhammadiyah Bogor 1. (1). 71-83.

Sulfemi, Wahyu Bagja. (2018). Manajemen Kurikulum di Sekolah. Bogor : Visi Nusantara Maju.

Sulfemi, Wahyu Bagja. (2018). Modul Manajemen Pendidikan Non Formal. Bogor: STKIP Muhammadiyah Bogor.

Sulfemi, Wahyu Bagja. (2019). Manajemen Pendidikan Berbasis Multi Budaya. Bogor : STKIP Muhammadiyah Bogor

Rismayanti, W. 2012. Masalah Perencanaan Pendidikan di Indonesia, (Online), (http://winirismayanti.blogspot.com/2012/12/masalah-perencanaan pendidikandi_15.html), diakses 15 Januari 2015. 